\title{
DETERMINATION OF FRICTION COEFFICIENTS OF FAST-GROWING TREE BIOMASS
}

\author{
Krzysztof Mudryk $^{1}$, Taras Hutsol $^{2}$, Marek Wrobel ${ }^{1}$, Marcin Jewiarz ${ }^{1}$, Barbara Dziedzic ${ }^{3}$ \\ ${ }^{1}$ University of Agriculture in Krakow, Poland; \\ ${ }^{2}$ State Agrarian and Engineering University in Podilya, Ukraine; \\ ${ }^{3}$ Cracow University of Economic, Poland \\ krzysztof.mudryk@urk.edu.pl,pro-gp@pdatu.edu.ua,marek.wrobel@urk.edu.pl, \\ marcin.jewiarz@urk.edu.pl, dziedzicbarbaraa@gmail.com
}

\begin{abstract}
The development of civilization, population growth and technological development cause an increasing energy demand. Solid biofuels have particular importance in the energy sector. The enormous potential of biomass in Poland is agriculture with related possibilities of setting up fast growing plantations, which have attracted attention of potential growers for the past years. One of the most important phenomena occurring in most processes of mechanical processing of biomass is the phenomenon of friction. The purpose of the work was to determine the coefficient of external friction (static and kinetic) of crushed shoots of robinia pseudoacacia and alder. Coefficients of friction were determined with different granulation of material and humidity. The prepared samples were subjected to friction tests on a steel surface. Analyzing the obtained results, it can be concluded that with the increase in the length of chips, marked coefficients of friction, both static and dynamic, increase. In the case of alder wood chips, the static friction coefficients $\left(\mu_{S}\right)$ ranged from 0.30.71 . However, the sliding friction coefficient $\left(\mu_{K}\right)$ ranged $0.24-0.63$. The values obtained for the robinia acacia chips are in a similar range $\left(\mu_{S}=0.36-0.7, \mu_{K}=0.27-0.64\right)$.
\end{abstract}

Keywords: coefficient of friction, biomass, chips, biofuels, alder, black locust.

\section{Introduction}

The development of energy and the use of renewable energy sources of biomass obtained from energy plants have increased interest in their physical and mechanical properties.It is caused by the necessity of obtaining products of the highest quality and limiting energy expenditure [1;2]. Research on physical properties, including mechanical ones, is the basis for the development of sustainable agriculture based on modern technologies which are low-energy and environment-friendly [3;4]. In technological processes the mass movement of plant materials very often occurs, which must be controlled in order to maintain its proper quality. At each stage of collection and processing of these materials, problems related to frictional resistance occur. Determination of the friction force occurring in the processing of materials is important, because it can facilitate their storage and transport $[5 ; 6]$. It also helps in the design of machines and devices as well as in the optimization of whole processes, reducing material and energy losses. The quantity of the external and internal friction coefficients is necessary to describe forces that act on the structural elements, based on the stress distribution in the material layer. It can be also used in strength calculations [7]. Simplification used in the design process can lead to numerous mechanical issues involving technical systems, like too weak drive trains, what leads to higher failure risk.

More and more research is focused on creating a correct description of the external and internal friction phenomenon. For plant materials the problem is complicated due to the heterogeneity of the structure, high variability of features and a variety of physical conditions[8;9]. The use of generally known theories and tests of the friction process made on structural materials for plant materials is an approximation of the actual friction processes and significantly simplifies the whole process. Plant materials in comparison to mineral centers, except for the discontinuous structure of cells and threephase structure, are also characterized by another mechanism of moisture interaction. The water contained in the air not only moistens the surface and fills the pores of wood particles (similarly as in the case of minerals), but also penetrates inside the grain, causing a change in its mechanical properties[10]. Despite the lack of problems in detecting and quantitative measurement of friction as a mechanical phenomenon, studying this process is not easy. Predicting of the friction for construction materials is widely developed, so that the repeatability of the friction results is small. The situation is different when describing this process for plant materials. From a physics standpoint, a single plant cell, constituting the basic element of the structure, is a plastic-elastic membrane filled with a mixture of liquid and gas, and no approximate solution to the problem of describing its deformation under the influence of external forces has yet been found [9].The development of material engineering enables 
the use of various surfaces of working elements to obtain optimal properties of the system of cooperating materials. Depending on the needs of the technological process, it is possible to obtain different values of friction forces thanks to the use of appropriate coatings or surface treatment techniques. On the one hand, the undertaken research will provide information on the value of coefficients of friction and, on the other, assess the possible problems, research challenges related to the optimization of the friction process parameters.

\section{Purpose and scope of work}

The purpose of the work is to determine the coefficient of external friction (static and kinetic) of crushed wood biomass of black locust and alder. Coefficients of friction were determined with different granulation of material and humidity.

The scope of the work included acquiring variable lengths of black locust and alder, then carrying out the drying process by seasoning to obtain a variable moisture mass. The prepared samples were subjected to friction tests on a steel surface on a test bench using the MTS testing machine. The results obtained were thoroughly analyzed and final conclusions were formulated.

\section{Materials and methodology}

The examined material was wood biomass of two species of energy plants, such as black locust (Latin: Robinia pseudoacacia L.) and alder (Latin: Alnus Mill.).

Black locust is a species of fabaceae and comes from North America, today's United States. It has been present in Europe since the 17th century, brought by a French gardener as a decorative tree, planted mainly in parks and gardens. Currently, its largest cluster is in Hungary, where due to the small soil requirements it was afforested by devastated land and forests during the First World War. Robiniapseudoacacia is one of the best plants grown in short rotation for the production of dendromass for energy purposes. It is characterized by an intensive growth at a young age, which lasts until the 10th or even 15th year of life, while the culmination in height increase is already in the first five years.It also has excellent regrowth from both the trunk and the roots, due to its low water content it dries relatively quickly, has favorable energy properties of wood, the dry biomass calorific value can even be $19.4 \mathrm{GJ} \cdot \mathrm{t}^{-1}[11 ; 12]$. There is also a close relationship between the planting of the plantation and its yielding. That is why it is recommended to plant it in robinia production plantations at a spacing of $1.5 \times 0.3 \mathrm{~m}$, which gives a cast of approx. 24.5 thousand pcs $\cdot \mathrm{ha}^{-1}[13 ; 14]$.

Alder (Latin: Alnus Mill.) - a type of trees from the birch family, which includes even about 50 species and they occur in the temperate zone and the northern hemisphere, among others Europe, Asia, North America and North Africa. In Poland, almost all over the country, there are naturally black alder species (Latin: Alnusglutinosa Gaertn) and gray alder (Latin: Alnusincana L. Moench). Alder is a pioneer plant with very low soil requirements, but most often it grows on wet soils, along rivers and wetlands. It is characterized by rapid growth, its most intensive growth is in the first five years, up to 20 years it falls to $75 \%$, and at the age of 30 to $33 \%$ of the initial increase [15;16]. The second important feature of the alder when it comes to its use for energy purposes is the ability to produce stalks that grow up very intensively, even at an advanced age.

The black locust and alder shoots from 3.5 years old plants grown on the experimental plantation of the University of Agriculture in Krakow were used for laboratory uses. The material of two species of energy plants was harvested in October 2017. The plant shoots were trimmed using secateurs and divided by diameter into segments with a length of approx. $0.50 \mathrm{~m}$. The shoots were then ground to give chips 15, 30 and $45 \mathrm{~mm}$ long (Fig. 1).The material prepared in this way was subjected to seasoning in openwork containers (natural drying, in the first period under the roofed shelter, and in the second in the laboratory room).Thanks to the seasoning process, lower humidity levels were obtained. For the friction tests the material was collected successively from October to March.

Before measurements of the friction parameters, the moisture content of the samples was determined, in accordance with the standard for solid biofuels PN-EN 14774-1: 2010E.The drying process was carried out in a laboratory dryer at $105^{\circ} \mathrm{C}$, the mass measurement of the sample before and after drying was carried out on a laboratory balance with an accuracy of $0.1 \mathrm{~g}$. 


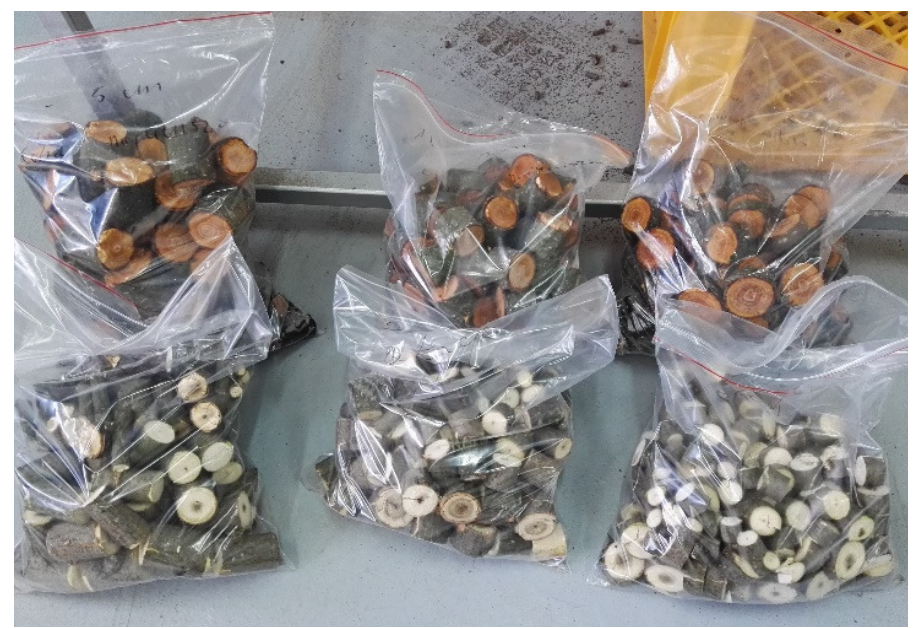

Fig. 1. Samples prepared for testing, in foreground black locust, on the second alder

There are many known friction measuring devices that differ in terms of how they measure and record results. This has an impact on the accuracy of the measurement and the obtained characteristics in the course of measurements, which is the basic criterion for choosing the measurement method. In the presented work to measure the external friction force of wood biomass chips, a station built on the basis of the MTS INSIGHT 2 testing machine with a measuring head $2000 \mathrm{~N}$ was used. The stand consisted of a horizontal base with a replaceable friction surface (e.g. steel plate) and a special measuring cassette measuring $300 \times 300 \times 300 \mathrm{~mm}$, in which the material was moving along the surface under the test. The measuring cassette is equipped with a precise chassis, eliminating friction against the tested surfaces. Forcing the movement of the measuring cassette on the given surface is carried out thanks to the movement of the head of the testing machine. The material in the measuring cassette in subsequent tests was loaded with a force of $20 \mathrm{~N}, 40 \mathrm{~N}, 60 \mathrm{~N}, 80 \mathrm{~N}$ (using special weights).

Wood chip samples used for the research (acacia and alder) had a different geometry, $15 \mathrm{~mm}$, $30 \mathrm{~mm}$ and $45 \mathrm{~mm}$ lenght. Measurements for both materials were made at the displacement speed $120 \mathrm{~mm} \cdot \mathrm{min}^{-1}$, at several humidity levels. The results of the friction test were recorded in the TestWork 4 software delivered by the manufacturer of the testing machine. After the test, the program created a graph of the dependence of the friction force of the material on its displacement on the tested substrate. To calculate the static friction coefficient, the maximum force was determined, when breaking of the static connection during the test occurs. To determine the kinetic friction coefficient, the mean value of the force from a specific friction measurement section was determined.

\section{Results and discussion}

Scheduled tests of the friction process of the tested chips were carried out at three humidity levels $\mathrm{M}$ for alder, respectively: $13.1 \%, 35.6 \%, 52.9 \%$ and for black locust: $11.5 \%, 25.2 \%, 34.4 \%$. The conducted tests of the friction process made it possible to determine the static $\left(\mu_{S}\right)$ and dynamic $\left(\mu_{K}\right)$ friction coefficients from the Culombs dependence $T=\mu \cdot N+b$. The following graphs (Fig. 2 and 3) present a summary of the results recorded for the chips with a length of $15 \mathrm{~mm}$ in extreme humidity values. All obtained values are presented in Table 1.

From the analysis of the obtained results it can be concluded that with the increase in the chips length both static and dynamic friction coefficients increased.In the case of alder wood chips, the static friction coefficients $\left(\mu_{\mathrm{S}}\right)$ ranged from 0.3-0.71. However, the dynamic friction coefficient $\left(\mu_{\mathrm{K}}\right)$ ranged $0.24-0.63$. The values obtained for robinia acacia chips are in a similar range $\left(\mu_{S}=0.36-0.7, \mu_{K}=0.27\right.$ $0.64)$. It should be noted that the humidity of robinia acacia in the harvest period is much lower than in the case of alder (about 52-54 \%) and amounts to about 34-36\%. This feature should be more strongly argued during choosing a crop for energy production. The dynamic friction coefficient for all tested chips was characterized by a lower value, which is classical for divided materials.

The obtained results are in the range of the values obtained by other researchers. In studies of the Bujang [10] team it was shown that the coefficient of friction of finely divided maize biomass (M$17.8 \%$ ) significantly changes depending on the friction surface.The largest coefficients of friction 
were characterized by the maize biomass-wood surface (0.41-0.44) and maize biomass-galvanized steel (0.66). The dynamic friction coefficients were about $42-45 \%$ lower. The lowest values were recorded for HDPE surfaces.

A similar effect of biomass moisture increase on the increase of the coefficients of friction was demonstrated in studies of crushed corn straw[17].
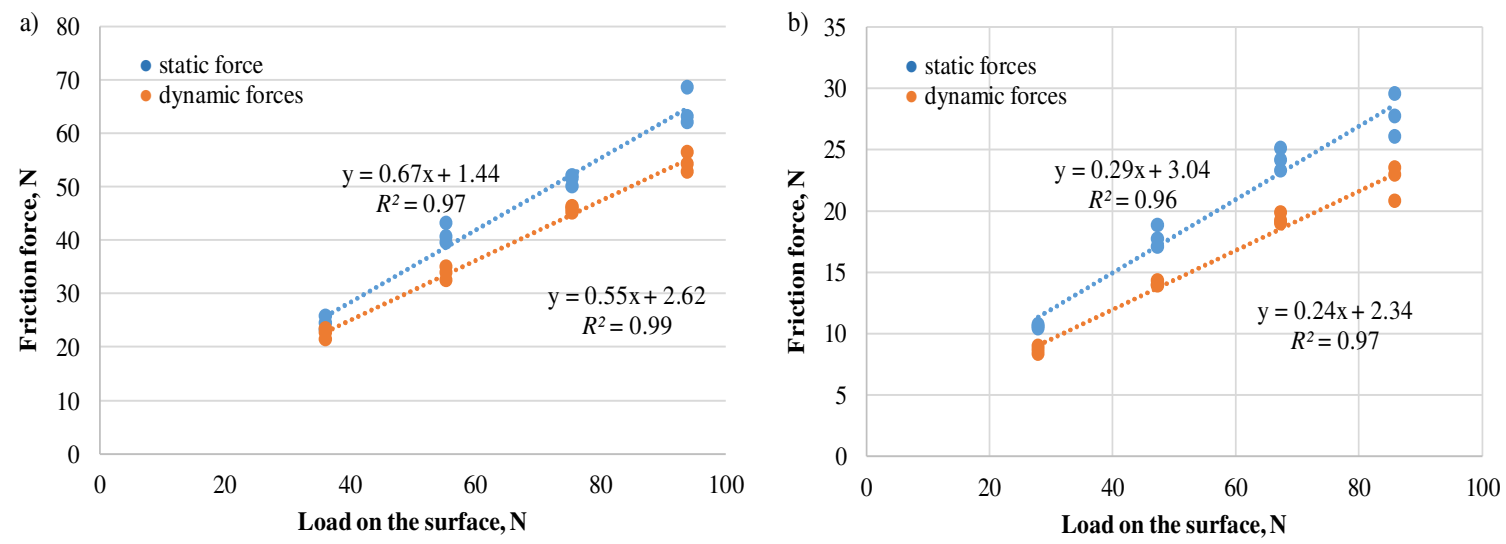

Fig. 2. Examples of friction force sample for alder wood chips, $l_{z}=15 \mathrm{~mm}$ : a - humidity $52.9 \%$; b - humidity $13.1 \%$
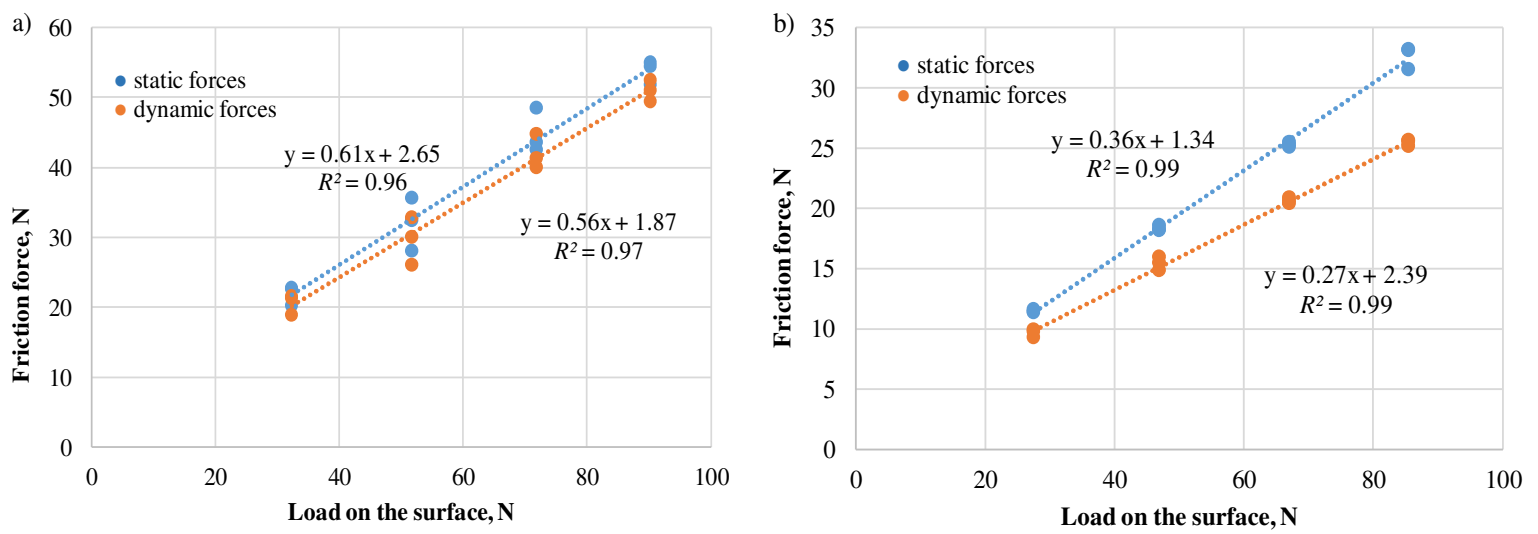

Fig. 3. Examples of friction force sample for robinia wood chips, $l_{z}=15 \mathrm{~mm}$ :

a - humidity $34.4 \% ; \mathrm{b}$ - humidity $11.5 \%$

Coefficients of friction of tested chips

Table 1

\begin{tabular}{|c|c|c|c|}
\hline $\begin{array}{c}\text { Humidity } \\
\boldsymbol{M , \boldsymbol { \% }}\end{array}$ & $\begin{array}{c}\text { Length of the } \\
\text { chips } \boldsymbol{~}_{\boldsymbol{z}}, \mathbf{m m}\end{array}$ & $\begin{array}{c}\text { Coefficient of static } \\
\text { friction } \boldsymbol{\mu}_{\boldsymbol{s}}\end{array}$ & $\begin{array}{c}\text { Coefficient of kinetic } \\
\text { friction } \boldsymbol{\mu}_{\boldsymbol{k}}\end{array}$ \\
\hline \multicolumn{5}{|c|}{ Chips of alder } \\
\hline 13.1 & & 0.30 & 0.24 \\
\hline 13.1 & 15 & 0.40 & 0.30 \\
\hline 13.1 & 30 & 0.60 & 0.48 \\
\hline 35.6 & 45 & 0.38 & 0.29 \\
\hline 35.6 & 15 & 0.52 & 0.42 \\
\hline 35.6 & 30 & 0.71 & 0.60 \\
\hline 52.9 & 45 & 0.67 & 0.55 \\
\hline 52.9 & 15 & 0.70 & 0.48 \\
\hline 52.9 & 30 & 0.70 & 0.63 \\
\hline
\end{tabular}


Table 1 (continued)

\begin{tabular}{|c|c|c|c|}
\hline $\begin{array}{c}\text { Humidity } \\
\boldsymbol{M}, \boldsymbol{\%}\end{array}$ & $\begin{array}{c}\text { Length of the } \\
\text { chips } \boldsymbol{l}_{\boldsymbol{z}}, \mathbf{m m}\end{array}$ & $\begin{array}{c}\text { Coefficient of static } \\
\text { friction } \boldsymbol{\mu}_{\boldsymbol{s}}\end{array}$ & $\begin{array}{c}\text { Coefficient of kinetic } \\
\text { friction } \boldsymbol{\mu}_{\boldsymbol{k}}\end{array}$ \\
\hline \multicolumn{4}{|c|}{ Chips of black locust } \\
\hline 11.5 & & 0.36 & 0.27 \\
\hline 11.5 & 15 & 0.41 & 0.35 \\
\hline 11.5 & 30 & 0.40 & 0.33 \\
\hline 25.2 & 45 & 0.38 & 0.32 \\
\hline 25.2 & 15 & 0.43 & 0.38 \\
\hline 25.2 & 30 & 0.54 & 0.51 \\
\hline 34.4 & 45 & 0.61 & 0.56 \\
\hline 34.4 & 15 & 0.66 & 0.59 \\
\hline 34.4 & 30 & 0.70 & 0.64 \\
\hline
\end{tabular}

The research clearly indicates that the coefficients of friction (static and kinetic) strongly depend on the properties of the raw material. Thus, the scope of the presented research will be extended to include other materials to develop information relevant to the design processes of biomass conversion systems.

\section{Conclusions}

1. The conducted research has shown that with the increase of humidity of the fragmented biomass of the examined tree species and with the increase of the length of the chips, the value of the static and kinetic friction coefficients increases.

2. In the case of the friction coefficients determined for the alder, their range of values and the course of changes were similar to black locust. The lowest values of the static friction coefficient $\left(\mu_{s}=0.3\right)$ and kinetic $\left(\mu_{k}=0.24\right)$ were determined for wood chips with a humidity of $13.1 \%$ and a length of $15 \mathrm{~mm}$. In contrast, the highest friction coefficients were determined at $52.9 \%$ humidity and $45 \mathrm{~mm}$ chip length $\left(\mu_{s}=0.70 . \mu_{k}=0.63\right)$.

3. The static friction coefficient of black locust was in the range of 0.36 (with a chip length of $15 \mathrm{~mm}$ and a humidity of $11.5 \%$ ) to 0.70 (for chips with a length of $45 \mathrm{~mm}$ and a humidity of $34.4 \%$ ). In contrast, the coefficient of kinetic friction varied from 0.27 (with a chip length of $15 \mathrm{~mm}$ and a humidity of $11.5 \%$ ) to 0.64 (for chips with a length of $45 \mathrm{~mm}$ and a humidity of $34.4 \%)$.

\section{Acknowledgements} Poland.

This research was financed by the Ministry of Science and Higher Education of the Republic of

\section{References}

[1] Mudryk K. Quality assessment for briquettes made of biomass from maple [Acer negundo L.] and black locust [Robinia pseudoacacia L.]. Agric Eng. 2011. pp. 115-121.

[2] Juliszewski T., Kwaśniewski D., Mudryk K., Wróbel M. Ocena wybranych parametrów biomasy pozyskanej z plantacji drzew szybkorosnących. Inżynieria Rol. 2012. pp. 89-97.

[3] Wrobel M., Mudryk K., Jewiarz M., Knapczyk A. Impact of raw material properties and agglomeration pressure on selected parmeters of granulates obtained from willow and black locust biomass. In: Engineering for Rural Development. 2018. pp. 1933-1938.

[4] Knapczyk A., Francik S., Pedryc N., Hebda T. Bibliometric analysis of research trends in engineering for rural development. In: 17th International Scientific Conference Engineering for Rural Development. Jelgava, LATVIA, 2018. pp.700-707.

[5] Wójcik A., Frączek J., Wota A.K. The methodical aspects of the friction modeling of plant granular materials. Powder Technol, vol. 344. 2019. pp. 504-513. doi:10.1016/J.POWTEC.2018.12.037 
[6] Wójcik A., Klapa P., Mitka B., Sładek J. The use of the photogrammetric method for measurement of the repose angle of granular materials. Measurement, vol. 115. 2018. pp. 19-26. doi:10.1016/J.MEASUREMENT.2017.10.005

[7] Wąsik R., Michalec K., Mudryk K. "Research reports variability in static bending strength of the ‘Tabórz' scots pine wood (Pinus sylvestris L.).” Drewno, vol. 59. no. 196. 2016. pp. 153-162.

[8] Ślipek Z., Frączek J., Złobecki A. Pomiar siły tarcia zewnętrznego materiałów roślinnych. Zesz Probl Post Nauk Roln. 1987. 321.

[9] Frączek J. Tarcie ziarnistych materiałów roślinnych. Zesz. Nauk. Akademii Rolniczej w Krakowie, 1999. 252 p.

[10] Molenda M., Horabik J., Grochowicz M., Szot B. Tarcie ziarna pszenicy. Acta Agrophysica. 1995. pp. 04-88.

[11] Szczukowski S., Tworkowski J., Stolarski M., et al. Wieloletnie Rośliny Energetyczne. MULTICO Oficyna Wydawnicza; 2012. 156 p.

[12] Lenz H., Pecenka R., Hartung E., Idler C. Development and test of a simplified method to calculate dry matter loss during open-air storage of poplar wood chips by analysing ash contents. Biomass and Bioenergy, vol. 94. 2016. pp. 258-267. doi:10.1016/J.BIOMBIOE.2016.09.011

[13] Manzone M., Bergante S., Facciotto G. Energy and economic sustainability of woodchip production by black locust (Robinia pseudoacacia L.) plantations in Italy. Fuel, vol. 140. 2015. pp. 555-560. doi:10.1016/j.fuel.2014.09.122

[14] Civitarese V., Faugno S., Picchio R., et al. Production of selected short-rotation wood crop species and quality of obtained biomass. Eur J For Res. Vol. 137. 2018. doi:10.1007/s10342-018$1122-3$

[15] Šporčić M., Seletković A., Ivankovic M. Biomass Production of Common Alder (Alnus glutinosa /L./ Gaertn.) in Pure Plantations and Mixed Plantations with Willow Clones (Salix sp.) in Croatia. Croat J For Eng, vol. 30, No2. 2009. pp. 99-112.

[16] Jaworski A. Charakterystyka Hodowlana Drzew Leśnych. Gutenberg, Kraków; 1994.

[17] Mani S., Tabil L.G., Sokhansanj S. MECHANICAL PROPERTIES OF CORN STOVER GRIND. Am Soc Agric Eng. 47(6). 2004. pp. 1983-1990. 